\title{
Philosophical Disputations at the University of Tartu 1632-1710: Boundaries of a Discipline
}

\author{
Meelis Friedenthal $^{a, c}$, Pärtel Piirimäe ${ }^{b, c}$ \\ ${ }^{a}$ University of Tartu Library \\ ${ }^{b}$ Institute of History and Archaeology, University of Tartu \\ ${ }^{c}$ Swedish Collegium for Advanced Study
}

\begin{abstract}
The article focuses on the definitions and divisions of philosophical disciplines in the disputations presented at the University of Tartu during the first two periods of its existence: Academia Gustaviana (1632-1656) and Academia Gustavo-Carolina (1690-1710). The classifications of philosophy in Tartu are studied in the context of competing traditions of classifying knowledge and the spread of novel pedagogical methods in early modern Europe. These trends were also reflected in the university statutes that were directly borrowed from the University of Uppsala, the parent institution of the academy in Tartu. The article shows that a strong emphasis on Ramist methods of teaching in the 1632 constitution and a similar prominence given to Aristotelianism in the 1689 constitution affected, to some extent, the priorities given to certain disciplines in the faculties but did not always determine the division of responsibilities between professors nor the conceptual tools and contents of instruction.

Keywords: history of philosophy, history of universities, classification of knowledge, Ramism, Aristotelianism, University of Tartu, early modern period
\end{abstract}

\section{Introduction: Systems of knowledge in early modern Europe}

In early modern European academia, new dialectical or logical methods were introduced with the aim of constructing philosophical systems to facilitate the introduction of a given subject to students. Classification and definition were viewed as two of the three central purposes of logic, or as instruments of human knowledge (next to inductio or demonstration) (Freedman 1999, 2). This early modern "mental mapping" became a widespread

Corresponding author's address: Meelis Friedenthal, University of Tartu Library, W. Struve 1, Tartu 50091, Estonia. Email: meelis.friedenthal@ut.ee. 
activity and significantly impacted the ways knowledge was organised into disciplines both within and without the universities. The classification of knowledge affected not only how the universe and human society were understood and interpreted by scholars and students but also had a more practical significance in schools, as it pertained to questions of competence and authority: who was in the charge of teaching what?

This article deals with questions of definition and classification on the basis of the philosophical disputations held in Tartu during both the Academia Gustaviana (1632-1656) and the Academia Gustavo-Carolina (1690$1710)$ periods. There are about 300 disputations that originate from the faculty of philosophy ${ }^{1}$ and could in the broadest sense be considered philosophical, i.e. encompassing "all matters relating to contemplation and action" (Freedman 1988, 200). The authors of these philosophical disputations often indicate the subfield to which the disputation belongs on the title page of the text, e.g. disputatio ethica or disputatio physica. It is well known that the boundaries of today's disciplines (like physics, ethics, mathematics) do not align themselves with the disciplinary boundaries in the early modern period. But it should also be noted that the boundaries between disciplines were not stable in early modern schools either, and they changed considerably during the seventeenth century. As disputations were one of the main tools for teaching and examination, much information concerning the dynamics of disciplines and general attitudes in the university towards new philosophical currents can be gathered from these school texts (Chang 2004).

The question of disciplinary boundaries clearly was of pedagogical value to both students and professors, and accordingly, several disputations in Tartu were solely devoted to the definition and classification of disciplines. In this matter, Tartu scholars could draw on a long tradition of ordering and organising the subject matter of philosophy that goes back to the classical and medieval periods. In the Middle Ages, two common ways of organising philosophy could be distinguished that authors themselves called the Peripatetic and the Platonic division (Iwakuma 1999, 165ff). The Peripatetic classification was based on Aristotle's division of all activity $(\delta\llcorner\alpha \dot{v o l \alpha})$ into "either speculative or practical or productive." ${ }^{2}$ This understanding was mediated to medieval philosophers through Cassiodorus, who divided philosophy into theoretical (also contemplative or speculative) and practical (or active) philosophy. ${ }^{3}$ Philosophia theoretica and philosophia practica were in

1 These disputations were mostly presided over by professors or masters of the arts faculty, sometimes also by professors who held joint professorships, e.g. in theology and physics.

2 Aristot. Met. 6.1025b25 (Aristotle 1933).

3 Cassiodorus used the concepts 'inspectiva' and 'actualis' (Iwakuma 1999, 165). In the early 
the Peripatetic tradition divided, respectively, into physics, mathematics and metaphysics, and ethics, oeconomics and politics. The discrepancy with the Platonic division of philosophy arose from divergent views on the position of logic in the general system of knowledge. The Peripatetics considered rhetoric, grammar and logic, the three primary liberal arts (trivium), as aux-

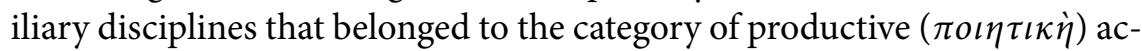
tivity. Also in Johann Heinrich Alsted's extremely influential Encyclopaedia of all sciences from 1630, logic is not part of philosophy but belongs to the discipline of philology, together with grammar and rhetoric (Alsted 1649, I, 23).

The Platonists, on the other hand, regarded logic as a part of philosophy. Isidore of Seville, for example, divided philosophy into physica (naturalis), ethica (moralis) and logica (rationalis). The first was further divided into arithmetica, geometria, musica and astronomia, the second into providentia, iustitia, fortitudo and temperantia, and third into dialectica and rhetorica (Iwakuma 1999, 166). In the Middle Ages, numerous smaller adjustments were made in these schemas, for example with regard to the position of grammar or the relationship between logic and dialectic, but the general schema was adopted by early modern scholars as an alternative vision to the Peripatetic system. ${ }^{4}$

Disputations at Academia Gustaviana dealing with classification generally approved of the Peripatetic division into theoretical and practical branches, e.g. Erici Stregnensis and Uraelius in Disputatio philosophica de philosophia in genere (1642), ${ }^{5}$ or Erici Stregnensis and Malmenius in a dis-

modern period, the Peripatetic division was followed by, e.g., Magnus Hundt (1501), Petrus Empoleius Horbelow and Christianus Johannes Stenbuchius (1643). Petrus Martinus Nigrinus (1603) speaks of philosophia intellectum and philosophia voluntatem (Ethica). These tables are reprinted in Freedman, 1999, 51-54. Also Alsted follows the dual classification: philosophia theoretica and philosophia practica (Alsted 1649, I, 23).

${ }^{4}$ Orazio Toscanella (in 1566) distinguished between natural (physics), moral (ethics, politics and oeconomics) and rational (logic and rhetoric) philosophy. Bernard Sassig proposed a similar system in 1684 , but with some notable differences, namely natural philosophy also included metaphysics and mathematics, and rational philosophy consisted only in dialectic and logic, excluding rhetoric. John Case (in 1599) preferred to replace the concept philosophia naturalis with philosophia realis. Finally, some systematisers, such as Magnus Hundt (in 1501), suggested a combination of the dual and tripartite classifications, calling the larger branches of knowledge speculativa and practica, and divided speculative knowledge further into realis (which consisted in physics, mathematics and metaphysics) and rationalis (which consisted in grammar, logic and rhetoric). For Hundt, philosophy is equivalent to the entire sphere of knowledge ("scientia") (All these schemas are reprinted in Freedman 1999, 51-56).

5 "[P]hilosophiam in duas partes commodissime dividi posse, nimirum speculativam seu Theoreticam quae in sola contemplatione acquiescit, et in Activam seu Practicam, quae praxin insuper requirit" (Erici Stregnensis-Uraelius 1642, thes. 29). 
putation with exactly the same title (Erici Stregnensis-Malmenius 1651, III, thes. 29-42; cf. Erici Stregnensis-Scarensis 1645, thes. 31). It is evident that the scholars in Tartu were aware of various ways to systematise philosophy but tended to prefer the more traditional dual classification. E.g., in a 1652 dissertation, Crellius and Laurentius put forward both possibilities: a tripartite classification (with natural, moral and rational philosophy) which they associate with the Stoics, and a dual classification between theoretical and practical philosophy (Crellius-Laurentius 1652, IV). They associate the latter with John of Damascus but it corresponded, of course, to the common Aristotelian distinction between philosophy concerned with knowledge and philosophy concerned with action and virtues. ${ }^{6}$ Here Crellius and Laurentius follow the Peripatetic explanation: theoretical philosophy studies necessary things that pertain to reason, and practical philosophy studies contingent matters that pertain to will. The first deals with the physical realm such as the earth and heaven, the other with the sphere of free human action. ${ }^{7}$ Thus the aim of these branches is, respectively, cognition and action. ${ }^{8}$

The long-existing classifications were, however, put under strain during the sixteenth century when new philosophies and new approaches to the acquisition of knowledge prompted a reconsideration of earlier schemas. First of all Ramism, the tradition that received its name from the sixteenthcentury French Huguenot educational reformer Petrus Ramus, helped to popularise the practice of systematising not only the universe but also knowledge itself using the method of creating dichotomies and presenting the results in the form of spatial models (Ong 2004, 9). Ramus became a controversial and polarising figure in Protestant universities in the late sixteenth and early seventeenth centuries, drawing as much opposition as support. ${ }^{9}$ Besides him, other authors such as Francis Bacon, Johann Heinrich Alsted, Thomas Hobbes and John Locke also devoted considerable energy to the endeavour of systematic classification of the sciences (Di Biase 2014). In addition, thinkers inspired by the pansophist ideas of John Amos Comenius engaged in the organisation of all human knowledge into encyclopaedic systems. These new schemas encompassed not only definitions but also pertained to the demarcation of boundaries between disciplines. Thus the vari-

${ }^{6}$ For John of Damascus's (675/676-749) classification, see Metallidis 2006, 342.

7 "Tales sunt actiones humanae liberae" (Crellius-Laurentius 1652, B2). Similarly Erici Stregnensis-Malmenius 1651, A4: "Objectum Philosophiae, sunt res tam necessariae, quam contingentes, quarum in Theoreticis, hae vero in Practicis pertractantur. Finis autem Philosophiae est speculari \& agere. Namque res necessariae intellectum cognitione veri; res vero contingentes voluntatem actione boni, perficiunt."

8 "Theoretica finis est contemplari, quod est in cognitione subsistere: Practicae vero operari, \& per media ad finem tendere" (Crellius-Laurentius 1652, B2).

9 For reception of Ramus, see Hotson 2007. 
ous and sometimes very different taxonomies and morphologies of sciences also give a general idea about the dynamics of the perceived value and importance of corresponding disciplines.

\section{Ramism in Tartu}

Interest in new pedagogical methods and in the modified taxonomy of sciences is already well reflected in the constitution (or statutes) of the University of Tartu. The first constitution was based on the new statutes for the University of Uppsala (1625-1626) that were co-authored by Johan Skytte, the Governor-General of Livonia, Ingria and Karelia. Skytte, who was appointed chancellor of the new university in Tartu, was greatly influenced by the pedagogy of John Amos Comenius and had prescribed Comenius's textbooks Vestibulum novissimum linguae latinae and Ianua linguarum reserata for Swedish schools (Ingemarsdotter 2011, 260-261). Comenius's ideas of new pedagogy stemmed foremost from a practical understanding of education and were in turn greatly influenced by the ideas of Petrus Ramus. Accordingly we can read from the statutes that professors should present their material in a clear manner, preferring the Ramist or Socratic approach, so that "metaphysical speculation and scholastic confusion" is expressly to be avoided. ${ }^{10}$

In the Academia Gustaviana setting we see that Ramism could be used as a tool to juxtapose Protestant philosophy to the Catholic philosophy of the Jesuits. The Jesuits had already established their school in Tartu in 1583 in the context of the Counter-Reformation with the intention to re-catholicise Livonia and also to influence Scandinavia (Garstein 1992, 268-273). Catholic theologians were mostly Aristotelian and also many early modern textbooks and commentaries on Aristotle that were used in Protestant universities were written by Catholic philosophers. Despite the fact that Martin Luther had already been opposed to Aristotelianism and had preferred the philosophy of Plato, no proper "Protestant" school philosophy had emerged after the Reformation. In the context of the growing dissatisfaction with Aristotelian philosophy from the beginning of the sixteenth century, Platonic, sceptical and Stoic arguments were presented against it, to name only some of the more popular strands. Ramus' new approach to education and philosophy emerged exactly in this context. In the Swedish empire its reception was generally favourable, in great part due to the positive attitude of Johan Skytte (cf. Hotson 2007, 113-114).

10 "Professores inprimisque Philosophiae disciplinas suas clare et perspicue, sine omnibus prorsus Scholasticorum perplexitatibus metaphysicisque speculationibus, tricis et subtilitatibus juventuti proponent, inque iis tradendis ordinem et methodum Socraticam seu Ramaeam accurate tenebunt, nec a rebus ipsis temere vnquam recedent" (Vasar 1932, 62). 
Petrus Ramus intended to revise all teaching and positioned himself squarely against Aristotelian tradition. He expressed scepticism against Aristotelian logic and metaphysics in general, stating that the "fourteen books of metaphysics are fourteen books of logical tautologies." was reflected in the statutes of Academia Gustaviana which prescribed the logic of Ramus and made no mention of metaphysics as a distinct discipline. The professors of philosophy were to be engaged only in politics, ethics, physics, history, mathematics, languages, rhetoric, logic and poetics (Vasar 1932, 31). There was also no mention of metaphysics in the extant lecture lists from the Academia Gustaviana period (Vasar 1932, 181-186, 200). ${ }^{12}$ Antimetaphysical attitudes are also present in the early disputations of Tartu that discussed philosophy in a general manner (e.g. Savonius-Anethulander 1632). One of the reasons for the preference of such an approach was the concern that too extensive metaphysical discussion could undermine the confessional theology that was seen as the only proper foundation for thinking (cf. Condren et al. 2006, 58-60):

[When] it appears that Philosophy gives us clear knowledge of nature and virtue, it would follow that we could by the same faculty come to understand piety, practice, honouring and invocation of God. ${ }^{13}$

In practice this meant that (Protestant) theology was viewed as the most important discipline, which also dealt with the metaphysical questions of philosophy. However, some later philosophers who could be considered (semi-)Ramist, most notably the encyclopaedist Johann Heinrich Alsted, still regarded metaphysics and ethics as the two main parts of philosophy (Alsted 1649, lib. I-III). Alsted deals with the classification and systematisation of sciences under the title hexiologia, technologia and archelogia. Hexiologia (from Greek $\tilde{\varepsilon} \xi \iota \varsigma$, meaning acquired or trained habit, skill) is the doctrine about the habit of the mind (de habitibus mentis). Technologia (from Greek $\tau \epsilon^{\prime} \chi v \eta$, meaning art or skill) is the doctrine of the properties, order and number of sciences (de proprietatibus, ordine et numero disciplinarum). Archelogia (from Greek $\dot{\alpha} \rho \chi \alpha \tilde{\imath} o \varsigma$, meaning ancient) is the doctrine of the principles of different disciplines (de principiis disciplinarum). Despite the official anti-metaphysical stance adopted under the influence of Skytte, the actual division of sciences in Tartu dissertations corresponded reasonably

11 "Quatrodecim metaphysicos libros quatrodecim logicarum tautologiarum cumulos esse statuo" (Ramus 1569, metaphys. Intro; cf. Ramus 2010, 15-16).

${ }^{12}$ It appears that the first lectio list was printed in 1653. There are handwritten lists from 1651 and 1655 . Printed lectio lists started to appear in Tartu with some regularity only after 1690.

13 "Quia per Philosophiam in mentibus nostris exoritur illustris naturae et virtutis cognitio, sequitur etiam per eandem in nobis excitari pietatem, cultum, honorem et invocationem Dei" (Savonius-Anethulander 1632, thes 50). 
well with the moderate approach taken by Alsted. This middle ground will therefore be employed here as a guide for the examination of disputations in more detail. Alsted's Encyclopaedia was used in Tartu from very early on ${ }^{14}$ and Academia Gustavo-Carolina disputations also cite him as an authority (Dau-Carstenius 1699). The aurea mediocritas position between Aristotelianism and Ramism is also supported in the disputation of Erici Stregnensis and Malmenius, which deals with different philosophical schools and their opinions, concluding that:

Presently there are three schools: Aristotelian, Ramist and the third is the mixture of them..$^{15}$ Thus we are not asserting that the opinion of this or that author has the highest authority and then fight valiantly in support of it as if it were our homeland we defend. These authors are like luminaries, not deities, and thus are to be honoured but not worshipped. In our opinion, the truth is always prudently to be held in sight-according to the old proverb: Plato is a friend, Socrates is a friend, but truth is a greater friend. ${ }^{16}$

\section{Theoretical philosophy}

Metaphysica, mathematica and physica were the disciplines that traditionally constituted theoretical philosophy (Erici Stregnensis-Scarensis 1645, thes. 39). During the Academia Gustaviana period there was, however, no separate position for professor of theoretical philosophy. The statutes instead stipulated one professor for physics and two professors for mathematics. Due to Ramist influences, we do not find even a single disputation in the Academia Gustaviana period that deals specifically with metaphysics, which is the first part of theoretical philosophy. There are several that deal with some metaphysical subjects, which traditionally are the ten categories of Aristotle: substance, quantity, quality, relation, place, time, position, state,

${ }^{14}$ E.g. Michael Savonius [P], Georgius Zethraeus [R], Disputatio II. de philosophia in genere quae est de arte, eiusque natura, cui analogustractatus[!] est peripateticorum de quinque habitibus intellectualibus ex 6. ethicorum desumptus, quem Alstedius sub titulo De hexilogia persequitur (Dorpat, 1632).

${ }^{15}$ The distinction between "pure Ramists" and "mixed Ramists" (who use Ramist methodology and borrow subject matter from Aristotle) was also made by Georgius Andreas Piscinus' classification of philosophical schools from 1624 (see Freedman 1999, 31).

16 "Sectae autem Recentiores sunt tres, Aristotelica, Ramaea, vel tertia ex his mixta. Hic tamen non asserimus, hujus vel illius Authoris opinionem tam magnifaciendam esse, ut pro ea, tanquam pro aris \& focis audacter sit pugnandum; quoniam isiti authores fuere quaedam Lumina, sed non Numina, \& sic sunt honorandi, non autem colendi; sed veritatem hic semper esse attendendam consultius judicamus; juxta tritum illud: Amicus Plato, amicus Socrates, magis tamen amica veritas" (Erici Stregnensis-Malmenius 1651, thes. 2425). 
action, affection. ${ }^{17}$ Abstract notions like unity, goodness, life, truth and death are also in essence metaphysical questions and the Tartu disputations that deal with these matters sometimes admit in the body of the theses that their study belongs to the field of metaphysics (e.g. Lidenius-Dryander 1654, art. $2 \$ 2$ ).

The title philosophiae theoreticae professor came into use in the GustavoCarolina period, indicating a change in attitude towards theoretical philosophy in general. Indeed we see that in the revised constitutions of 1689 that were based on the 1655 statutes of Uppsala University (Rauch 1943, 29), it is stipulated that metaphysical terms and distinctions should be explained (by the professor of logic) (Constitutioner 1690, 59v). Accordingly, we have a textbook from this period that deals specifically with metaphysics, namely Gabriel Sjöberg's Metaphysica contracta. This short work gives a concise overview of the subject matter from the Peripatetic perspective and is intended for school use in the academia of Tartu (Sjöberg 1692). ${ }^{18}$ In the Gustavo-Carolina period, metaphysics was usually considered to be the first part of theoretical philosophy and was therefore also called "the first principles," which was also the preferred name given by Aristotle (and Descartes) to this kind of activity. ${ }^{19}$ This was taken to mean philosophy in totality, since metaphysics deals with questions about everything that "is, or is not, of actual or real or objective or potential or enunciative essence." ${ }^{20}$ Sjöberg, however, warns that we need to be careful not to include in metaphysics things that pertain to material objects because only abstract objects are the subject matter of this part of philosophy (Sjöberg 1692, 17). Other names that can be applied to metaphysics are philosophia transcendentalis, ontologia, prudentia and sapientia (Sjöberg 1692, 9). Metaphysics and ontologia were also mentioned as subjects in the lecture lists of the Gustavo-Carolina period (Catalogus 1694; Catalogus 1699).

Sjöberg indicates in his work that metaphysics is sometimes also called theologia naturalis, but immediately disagrees with this designation together with "the most famous philosophers" and points out that this field of study forms a separate discipline, namely pneumatica (science about spiritual mat-

${ }^{17}$ E.g. Ludenius-Bostadius 1641; Erici Stregnensis-Holstenius 1647; cf. Sjöberg 1692, 104-108; Alsted 1649, 23.

${ }^{18}$ Tõnu Luik bases his description of metaphysics in Tartu on the same book (Ruutsoo and Luik 1982, 188-189).

${ }^{19}$ Such synonyms for metaphysica are also presented in Sjöberg, Metaphysica contracta, p. 8. Sjöberg does not mention Descartes here though he is well aware of his metaphysics. This is evident from several disputations where he acted as praeses and where Descartes' works are extensively quoted: e.g. Sjöberg-Edenius 1690; Sjöberg-Westermann 1692.

20 "Quodlibet est, vel non est, vel actuali vel reali, vel objectiva, vel potentiali vel enunciativa essentia” (Sjöberg 1692, 9). 
ters) (Sjöberg 1692, 13). In a purely Aristotelian framework, it was indeed the task of metaphysics to consider the soul or spirit in a general sense, but the soul in a stricter or narrower sense was not the subject of metaphysics but was instead discussed under physics. ${ }^{21}$ This stemmed from the conception that the soul was always connected with matter as its actuality, and in this sense the anima vegetativa, anima sentiens and anima rationalis were actually aspects of a living organism. This kind of Aristotelian understanding of categorising the soul is also visible in some other disputations of the Academia Gustaviana period. These disputations discussing the soul are entitled simply as disputatio philosophica ${ }^{22}$ or disputatio physica. ${ }^{23}$ Three disputations dealing explicitly with Aristotle's work De anima that Johannes Erici Stregnensis supervised during the years 1650-1651 are also clearly Peripatetic. However, during the years 1644-1647, Johannes Gezelius the Elder (1615-1690) supervised nine Greek disputations (nos. seven and eight are not extant) that explicitly belong to the field of pneumatological studies (Korhonen 2016). These are strongly influenced by the Encyclopaedia of Heinrich Alsted. Pneumatica, as understood by Alsted, deals with matters that are in essence somehow between physics and metaphysics, encompassing angelographia, daemonologia, psychologia and ctistica (from Greek $\kappa \tau i \sigma \iota \varsigma$, meaning "creation") (Alsted 1649, I, 23). There are also two disputations from the Gustaviana period which identify the subject in the title of the work as psychological. ${ }^{24}$

The Academia Gustavo-Carolina period nearly wholly neglects the Aristotelian concept of the tripartite soul and gravitates towards the Platonic understanding, often citing Augustine (e.g. Sjöberg-Kiemmer 1698) and together with him Descartes (e.g. Sjöberg-Krook 1696). The disputations deal mainly with the anima rationalis or human mind, even discussing critically the argument that animals do not possess any soul and are purely mechanical (Dau-Carstenius 1699). There is one disputation from the Gustavo-Carolina period that identifies itself as pneumatological ${ }^{25}$ and also the lecture list of 1694 presents Michael Dau explaining pneumatological questions (Catalo-

21 "Absolutam vero animae considerationem Physicus ad Metaphysicam remittit" (Erici Stregnensis-Flojerus 1651, thes. 8).

${ }^{22}$ E.g. Petrus Schomerus [P], Christiernus Osaengius [R], Disputatio solennis philosophica de anima vegetativa (Dorpat, 1634 ).

${ }^{23}$ E.g. Johannes Erici Stregnensis [P], Matthias Wåltt [R], Disputatio physica de anima rationali (Dorpat, 1652).

${ }^{24}$ Petrus Schomerus [P], Nicolaus Prytz [R], Disputatio psychologica de anima in genere (Dorpat, 1634) and Johannes Georgius Preusius [P], Stephani Halenus [R], Disputatio psychologica de sensibus (Dorpat, 1655).

${ }^{25}$ Daniel Sarcovius [P], Gudmundus Krook [R], Disputatio pneumatologica de mente humana in statu separato (Pernau, 1699). 
gus 1694). From the Gustavo-Carolina period we find the only disputation dealing with apparitions or ghosts (and also mentioning angels and demons) (Cameen-Barthelius 1693) but there are no philosophical disputations dealing with creation, which according to Alsted was one of the subtopics of pneumatology.

Mathematica. The statutes of the Academia Gustaviana stipulate two professors for mathematics (out of 11 for the whole faculty of philosophy), but most of the time only one position was filled. Nonetheless, this indicates the new importance mathematical sciences gained in Europe during the sixteenth and seventeenth centuries (Imhausen and Remmert 2006). The statutes stress that mathematics should be accommodated for civil use, which was also the general sentiment in Swedish territories-mathematics is not useful per se but with regard to its applicability in warfare, fortification, navigation, commerce, architecture, etc. (Kallinen 2006, 111-112). Academia Gustaviana statutes also indicate a certain division of mathematics. The instruction of mathematics was divided into three principal subfields where the task of the Euclideus was to teach the arithmetics and geometrics of Petrus Ramus (based on the explication of Lazarus Schöner), Archimedeus was to teach music, optics, isorropia (load-balancing capabilities) and mechanics, while Ptolomaicus was concerned with spheres, the movements and theories of planets, geography and architecture (Vasar 1932, 64). The mathematics chairs as named in the statutes did not come into use. This was analogous to the situation in Uppsala and Turku (cf. Kallinen 2006, 113; Kallinen 1995, 48). The professors titled themselves either traditionally as professor of arithmetics or professor of astronomy or even as "superior" and "inferior" professor of mathematics (respectively Savonius and Schelenius). The latter division indicates that one professor was engaged in mathematics of the supralunary and the other of the sublunary sphere. Conrad Quensel, the last professor of mathematics in the Gustavo-Carolina period, titled himself as superiorum et inferiorum mathematum professor.

In general, it was understood in the disputations that mathematics was a science that dealt with quantity. ${ }^{26}$ Although metaphysics and physics also discussed quantity, mathematics dealt specifically with distinct (or limited) quantities. ${ }^{27}$ Already in antiquity, mathematics was usually divided into arithmetica, geometria, musica and astronomia, and this was also the most common conception in the disputations of Academia Gustaviana (e.g. Erici

\footnotetext{
26 "Mathesis est scientia, quantitatem quatenus terminata est, contemplans" (Erici Stregnensis-Gruuf 1652, thes. 7).

27 "Quamvis enim de Quantitate agat Metaphysica, Physica et Mathematica: Metaphysica tamen Quantitatem considerat sub ratione extensionis, Physica sub ratione affectionis; at Mathesis sub ratione terminationis" (Schelenius-Arvidi Stregnensis 1645, thes. 19).
} 
Stregnensis-Platinus 1641, thes. 1). This division was based foremost on Boethius (who in turn relied on the Arithmetica of the second-century neoPythagorean scholar Nicomachus of Gerasa), who understood that quantity, as it is discrete, belongs to the field of arithmetic, and as it is continuous, to the field of geometry. These principal divisions were in turn divided into subfields where music (sometimes also called harmonia) was a subfield of arithmetic because it studied relations of discrete quantities. ${ }^{28}$ Astronomy was a subfield of geometry because it studied movements and rotations, whereas geometry studied static continuous quantities (cf. Boethius 1983, 71). In Academia Gustavo-Carolina period lectio lists (Catalogus 1694; Catalogus 1695; Catalogus 1696), we find that Sveno Dimberg lectured on the mathematics of Isaac Newton.

Physica. It has been noted that there does not appear to be any clear distinction between Lutheran and reformed universities in reference to the teaching of natural philosophy or physics (Hotson 2007, 16-25; Meer 2014, 101-130, 118-119). Neither did the Ramists develop their own system of physics as they were more interested in dialectic. In the statutes of Academia Gustaviana, we see that it was in fact the task of the professor of medicine to lecture on the problems of physics (based on a textbook by Johann Magirus) (Vasar 1932, 63). Thus according to the statutes, physics did not belong to the philosophical disciplines at all (cf. Kallinen 1995, 48-49). In practice, however, the professor of physics was a joint professorship with astronomy or arithmetic during the Academia Gustaviana period. There were also some years when there was no professor of physics present. Sometimes physical disputations were held by other professors, e.g. by Heinrich Oldenburg, who was professor of poetics and rhetoric (Oldenburg-Prytz, 1633). All these facts seem to indicate the relative unimportance of physica as a separate discipline in the Academia Gustaviana period. Only in the revised constitutions of the Gustavo-Carolina period did physics appear as a sub-discipline of philosophy (Constitutioner 1690, 65v). This is a deviation from the 1655 Uppsala statutes, where physics was not mentioned as a philosophical discipline. Instead, it was still the task of the professor of medicine to provide instruction in physics (Annerstedt 1890, cap. XIX). However, during the second period of academia in Tartu, professors rarely titled themselves as professor of physics (only Daniel Sarcovius did so), and the title 'professor of theoretical philosophy' was generally used.

In defining physics, it was commonly accepted that the object of physical studies was composed of matter and form, and was thus corruptible (Erici Stregnensis-Flojerus 1651, thes. 14) and, according to Aristotle's definition

${ }^{28}$ Among Tartu disputations there are none that deal with music, however there are some orations devoted to the praise of music. 
(Metaph. 1025b18-20), had inner principles of change and being at rest (cf. also Scharf 1626, 2 and Alsted 1649, II, lib. 13.1.1). Alsted understood this in a strict sense. So according to his definition, physics would include questions about the matter of heaven, stars and planets, but exclude questions about eclipses, time, the calendar and the like, which would belong to the field of mathematics. Likewise, discussions about refraction, reflection and colour are, according to Alsted, not physical (because they do not deal with material objects), but optical and therefore belong to the discipline of mathematics.

Physical disputations of the Academia Gustaviana period are usually entitled disputatio physica or disputatio philosophica, a few times also indicating that the work deals with two different fields (e.g., disputatio physicoastronomica) (Erici Stregnensis-Schonbergius 1643). We can see that sometimes physics was held to be synonymous with philosophy in a general manner, as there are several works that define their subject matter in the theses themselves as physical (on the matter of heaven, the vegetative soul, the element of air, etc.) but do not indicate so in the title. Overall, the works follow the principles described by Alsted reasonably closely, and thus it is altogether not surprising to find a work dealing with plants under physics (Erici Stregnensis-Arvidi Stregnensis 1647).

The main body of physical disputations from the Academia Gustaviana period is heavily influenced by Peripatetic physics. A considerable portion of these disputations (33 works) belong to the series of commentaries on Aristotle's Physics that were presided over by Johannes Erici Stregnensis. ${ }^{29}$ Besides Aristotelian works there is a series of four uranological disputations of Petrus Schomerus where neo-Platonic understanding of astronomy is discussed (Schomerus-Risingh 1634, etc.), and Paracelsian influences regarding the composition of substances are noticeable (Erici Stregnensis-Holstenius 1646, cf. Rein 2008; Rein 2016).

In spite of the fact that Aristotle's works on natural philosophy were prescribed for the teaching of physics in the revised constitutions of Academia Gustavo-Carolina (Constitutioner 1690, 56v), ${ }^{30}$ we find no disputations there that deal exclusively with Aristotelian theory. An interesting series of 13 academic exercises presided over by Gabriel Sjöberg, Exercitationes academicae XIII. seu theses physicae selectiores (Dorpat, 1692) gives a good overview of the topics that were discussed in lectures. These exercises present Cartesian ideas about physics, mostly abandoning Aristotelian explanations, but at the

${ }^{29}$ First of the series is Johannes Erici Stregnensis [P], Petrus Undenius [R], In octo libros physic. Arist. $\pi \epsilon \rho \grave{i} \tau \tilde{\eta} \varsigma \phi v \sigma \iota \kappa \tilde{\eta} \varsigma \dot{\alpha} \kappa \rho o \alpha ́ \sigma \epsilon \omega \varsigma$ sive de naturali auscultatione disputatio prima (Dorpat, 1642).

${ }^{30}$ The professorship for physics is not mentioned at all in the 1655 Uppsala statutes (Annerstedt 1890 , cap IXI). 
same time retaining much of the vocabulary. Also, in other non-physical disputations where Sjöberg acted as the presider, Descartes and Cartesian authors like Le Grand or Rohault are cited. There are also disputations presided over by other professors that to a greater or lesser extent present the new theories of Descartes and also Robert Boyle (Dimberg-Höjer 1693).

\section{Practical philosophy}

As we have seen above, in all common early modern classifications of philosophy, practical philosophy formed a separate branch, no matter whether there were two or a larger number of branches in a specific classification. Tartu disputations from the 1650 os that deal with the discipline of philosophy in a general manner also outline the realm of practical philosophy: it is the discipline that deals with action, or more specifically, it is concerned with the question of how to act well or virtuously. ${ }^{31}$ Further division of practical philosophy into three fields-ethics, oeconomics (family life) and politics-was strongly entrenched in early modern scholarship, and this was also followed in Tartu without any questioning (Erici Stregnensis-Scarensis 1645, thes. 4445; Laurentius-Crellius 1652, IV). In total, 114 disputations were published in Tartu that could be classified as belonging to the field of practical philosophy: 65 of them to the narrower sphere of ethics, 45 to politics and 4 to oeconomics. In the 1630 s and 1640 s, disputations in the field of ethics were called either disputatio ethica or disputatio practica, which shows that the more general term practica was in fact synonymous with ethics. In the 1650 , this confusing practice ended and the term practica disappeared from the titles of disputations on ethics. At the same time, another alternative term, disputatio moralis, appeared. Ethica and moralis were also used synonymously in titles during the Gustavo-Carolina period. The dissertations on politics and family life were, on the other hand, entitled more specifically politica and oeconomica in both periods; the term practica was used only in a single exceptional case (Wexionius-Ekaeus 1655). ${ }^{32}$

The 1626 constitution in Uppsala and the 1632 constitution in Tartu established that a "professor of ethics and politics" should teach in the field of philosophia civilis (Annerstedt 1877, 250, 278; Vasar 1932, 65). ${ }^{33}$ This stipu-

31 "Finis autem Philosophiae est speculari et agere. Namque res necessariae intellectum cognitione veri; res vero contingentes voluntatem actione boni, perficiunt" (Erici StregnensisMalmenius 1651, A4v).

${ }^{32}$ Many disputations on practical philosophy did not refer to a specific subdivision of philosophy.

${ }^{33}$ Professors of logic and ethics: Michael Savonius (1632-1650); Petrus Lidenius (1651-1656). Professors of history and politics: Andreas Sandhagen (1643-1645, 1649-1650); Joachim Crellius (1647-1652); Olaus Wexionius (1653-1656) (Piirimäe 1982, 279-281). 
lation was well in line with the usual classifications but in actual fact it was not followed in Tartu, where no special professorship for practical philosophy was created. The duties of teaching practical philosophy were divided between the professor of logic, who assumed the title "professor of logic and ethics," and the professor of history, who from 1643 served as the "professor of history and politics." The fact that a professorship for practical philosophy or politics was not established in Tartu was probably due to lack of funding but the decision to split the professorship in this particular manner also indicates the strong influence of humanist curriculum where politics as a practice-oriented discipline was primarily taught by means of classical histories. Indeed, in the statutes the remit of the professor of philosophia civilis, with respect to the teaching of politics, largely coincided with that of the history professor. The instruction of politics was not to be restricted to theoretical precepts alone but it was to be taught in close connection to the analysis of historical states, both on the example of the then current Swedish state and (ancient) history. ${ }^{34}$ It is clear that a historical rather than a syllogistic approach was more suitable for this purpose. The history professor, for his part, was told not to just lecture on world history using the traditional schema of four monarchies but also demonstrate the applicability of historical knowledge to ecclesiastical, political and economic administration, and compare historical examples to the present-day Swedish state. ${ }^{35}$ It thus made perfect sense to subsume these two fields under one professorship. The lecture list from 1653 specifies that the professor of politics and history should teach the precepts of politics methodically based on the example of specific states, and his history lectures had to be based on Sleidan's synopsis of four monarchies, in conjunction with the history of Sweden. ${ }^{36}$

To provide the context for the developments in Academia Gustaviana, it is worth noting that when teaching at Uppsala was reformed in the 1620 , whose responsibility the teaching of practical philosophy should be was unclear there as well. Karl IX had proposed at the Diet in 1604 that a "juris consultus" should teach law, ethics and politics. Politics was at this time occasionally understood in a broad sense as comprising a range of disciplines, thus a draft of university statutes from 1606 divided stipendiaries in two groups: students of theology and students of politics ("qui politicae operam dabunt"). The latter group should listen to lectures "in eloquentia

34 "[...] ut in polyticis Status hujus regni mentionem faciat, usum autem in libris regum, in Herodoto, Thucydide, Diodoro Siculo, Polybio, Livio etc. monstrabit [...]" (Vasar 1932, $65)$.

35 "Usum historiarum in Ecclesiae, polytiae et Oeconomiae administratione ostendet, cumque praesenti Reipubl. Statu veterum Rerumpubl. exempla conferet" (Vasar 1932, 65).

36 “[...] Quatuor Monarchiarum Expositionem ex Synopsi Sleidani conjugendo cum ea Historiam Patriam [...]” (Catalogus 1653). 
vel ethicis et politicis, vel historiis et legibus" (Malmström 1985, 14-15). The programme of Karl IX was put into practice in 1609 when Johannes Messenius was nominated professor of law and politics. ${ }^{37}$ After he left in 1613, the chair was remodelled into the professorship of "politices, historiarum et juris." Jonas Magni, the holder of the chair since 1614, often called himself "professor of practical philosophy" but he was also called "politices and historiarum professor" (Malmström 1985, 23).

Following the established tradition, Johan Skytte in his draft of a new constitution (from 1620 or 1621) did not see the need for a special professorship of practical philosophy but stipulated that politics and ethics should be taught by the second law professor together with Roman law (Annerstedt $1877,168)$. In July of 1621 , King Gustav Adolf issued an order that specified the number and the disciplinary realm of professors in Uppsala. There were some small but notable deviations from Skytte's draft. The second law professor was to teach ethics (but not politics) in conjunction with Roman law ("institutiones juris civilis, så och philosophiam moralem"), and the realm of politics was adjoined to history (politices et historiarum professor), whereas Skytte's draft had envisioned a pure historical professorship (historiarum och antiquitatum) (Annerstedt 1877, 168-172). However, unlike later in Tartu, the vision of a joint professorship of politics and history was not realised in Uppsala. Instead, politics became the field of two different, and to an extent competing chairs: the professorship of eloquence and politics that was established in 1622 by Skytte (Annerstedt 1877, 183-201), and the professorship of philosophia civilis (i.e. ethics and politics) that was established according to the 1626 statutes. ${ }^{38}$

The constitution of Academia Gustavo-Carolina from 1689 that was based on the new Uppsala constitution from 1655 stipulates again that a professor philosophiae civilis should teach "on moral and political doctrine." 39 This time a special professorship for ethics and politics was duly established, just like in Uppsala, and three scholars of Swedish origin served in that capacity from 1690 to $1710 .{ }^{40}$ In dissertations, the discipline of these professors was variously referred to as "moral philosophy," "moral and civil philosophy," or "moral and civil philosophy and natural law," referring in the latter case to the particular duty of these professors, not the law professors, to teach the doctrine of natural law (cf. Rauch 1943, ch. 16). Oeconomics, the third part

${ }^{37}$ Messenius called himself "politices et juris utriusque professor" in dissertation titles (Malmström 1985, 20, note 41).

${ }^{38}$ These professors were called "Pract. Philos. Prof." or "Philos. Moral. \& Civil. Prof" in disputation titles.

39 “[...] om doctrine morum och Politicis" (Constitutioner 1690, 111).

${ }^{40}$ Gustav Carlholm (1690-1692), Gabriel Sjöberg (1692-1702) and Andreas Palmroot (17011710) (Rauch 1943, 308-311). 
of practical philosophy, was clearly seen as being marginal next to ethics and politics, and it did not appear in the titles of professors.

In a 1653 disputation entitled $A$ discourse on the nature of ethics, defended by Johannes Sundius and presided over by Petrus Lidenius, two alternative definitions of ethics are proposed: a broader (or general) definition which equates ethics with the entire field of practical philosophy, and a narrower (or special) definition. Hence the field of ethics in the broader sense can be divided into politics (which informs magistrates on how to apply ethical principles to governing the state), oeconomics (which informs the heads of families on how to run a household) and ethics proper (or ethics in the special sense) which in general terms teaches how to live (LideniusSundius 1653, IV-V). From this follows the definition of ethics as prudence that directs the free actions of humans and informs their souls to strive for the supreme good by means of virtues. ${ }^{41}$ In a usual manner, Lidenius and Sundius also discuss synonyms, which in the case of ethics are philosophia morum, philosophia civilis, and ars vivendi or doctrina bene vivendi, but they recommend to stick with 'ethics' as the concept most common in schools and academies.

This disputation was a characteristic example of Academia Gustaviana disputations that dealt with a broad subject field by means of nominal and real definitions (including etymology, synonyms and homonyms) and further distinctions into sub-disciplines. An almost identical disputation on ethics had been presided over by Michael Savonius, the first professor of logic and ethics (Savonius-Laechlin 1644), and similar student works were also presented in the fields of politics and oeconomics. The disputation $\mathrm{On}$ the nature and constitution of politics in general by Erici Stregnensis and Trottonius begins with statements on the centrality of the discipline of politics to human life. The authors refer to Aristotle's well-known proposition that politics is the master science (disciplina architectonica) that comprises all the other sciences, including ethics because the good of the city is a more complete thing than the good of the individual (Aristotle 2000, bk I, ch 2; Erici Stregnensis-Trottonius 1640, thes. I.4-5; cf. Wexionius-Ekaeus 1655, thes. II). The broad definition of politics by Aristotle and Plato as being equivalent with the entirety of practical philosophy (scientia quae omnes actiones gubernat) is, however, viewed by the authors as a "suspicious usurpation." In the strict sense, they write, politics should be viewed as a part of practical philosophy, distinct from ethics and oeconomics, the purpose of which is the good government of a city (Erici Stregnensis-Trottonius 1640, thes. I. 11-12;

${ }^{41}$ "Definitio. Ethica est prudentia, quae liberas hominis actiones in genere dirigit, ejusq. animum per virtutes ad summum bonum consequendum informat" (Lidenius-Sundius 1653 , VIII). 
similarly also Erici Stregnensis-Scarensis 1646, thes. 16). Further discussion is conducted entirely along Aristotelian lines, emphasising the nature of politics as prudence and habitus, rather than a strict science that deals with necessary things. Trottonius indeed suggests "prudence" as a synonym for politics, whereas for Scarensis the suitable synonyms would be doctrina civilis, doctrina de institutione Reipublicae or de regno. The general disputations on oeconomics offer nothing original but stay close to traditional Aristotelian discussion. Ericus Andreae and Johannes Nicolaus Trätz define oeconomia as the discipline that teaches how to correctly set up primary human societies, i.e. families, and continue to discuss their formal and material aspects, finis universalis et particularis, causa efficiens universalis (i.e. God) and particularis (i.e. desire for comfortable life) (Andreae-Trätz 1640; similarly Ludenius-Langius 1639).

These disputations from Academia Gustaviana show that with regard to practical philosophy there was no inherent conflict between (neo-)Aristotelian scholarship and the officially sanctioned Ramist methods of teaching. There were indeed, as pointed out by Matti Sainio, disputations presided over by Michael Johannis Savonius that, for example, juxtaposed Ramist definitions of ars and scientia to Peripatetic conceptions (Savonius-Laechlin 1644, thes. 32-42; Sainio 1962, 267-268), but Ramist philosophy was too thin to offer an alternative content to the Aristotelian scholarship. This is also evident when we look at what textbooks the statutes of 1632 recommended to professors of civil philosophy. This chapter in the Academia Gustaviana constitution is lifted verbatim from the Uppsala statutes of 1626 . They prescribe Johannes Althusius, the author of the widely known Politica methodice digesta, or Theophilus Golius, ${ }^{42}$ an ethics professor from Strasbourg who had published commentaries on Aristotle's Nicomachean ethics and Politics (Golius 1592, Golius 1622). The choice of Althusius, who consciously organised his doctrine of politics according to Ramist logic (Carney 1995, xii), ${ }^{43}$ was well in line with the general attitude of the statutes. Somewhat surprisingly, his name was included in the statutes not by Skytte but in the course of a later revision, probably by Axel Oxenstierna (Ingemarsdotter 2011, 227; Runeby 1962, 171). It is not so clear, however, whether or not Althusius was in fact used in Tartu in the Academia Gustaviana pe-

\footnotetext{
42 "Philosophia civilis Professor Ethica et Politica aut Althusii aut etiam Golij tradet [...]" (Vasar 1932, 65).

43 "I have attempted, most distinguished and learned men, honourable relatives and friends, to restate in an appropriate order the many political precepts that have been handed down in various writings, and to find out whether a methodical plan of instruction according to the precepts of logicians can be followed in these matters" (Althusius 1995, Preface to the First Edition (1603)).
} 
riod. ${ }^{44}$ The disputations on politics do not mention his works, referring instead often to Bartholomeus Keckermann, another widely used German reformed philosopher who has been classified as "semi-Ramist" (e.g., Erici Stregnensis-Trottonius 1640; Sandhagen-Liebeheer 1643; cf. Hotson 2007, ch. 4). The fact that the Aristotelian Theophilus Golius was offered as an alternative to Althusius shows that neither Skytte nor Oxenstierna took a strong view about either including or excluding classical Aristotelian scholarship. The actual practice of teaching demonstrated that Aristotelianism in fact occupied a central place in Academia Gustaviana during the following decades, just as it did in Uppsala.

It is not without a certain irony that when Aristotle took pride of place in the university statutes of 1689, the heyday of Aristotelianism had in fact already passed. The constitution of 1689 stipulated that "Professor philosophia civilis skall ...läsa uth Aristotelis Ethicam och Politicam" (Constitutioner 1690, 111). The statutes of Academia Gustavo-Carolina were largely copied from the "new" statutes of Uppsala dating from 1655, i.e. from the time when Aristotelianism was at its peak in Uppsala (Annerstedt 1890). 35 years later, however, the intellectual atmosphere had changed both in Uppsala and in Tartu. Just like Cartesianism changed the discipline of theoretical and natural philosophy, natural law had transformed the teaching of practical philosophy (Lindborg 1965; Lindberg 1976; Rauch 1943, ch. 16). The most influential and productive professor of moral and political philosophy in Tartu was Gabriel Sjöberg, who was hardly interested in Peripatetic distinctions and definitions. The disputations on ethics presided over by him were far less indebted to Aristotle than to Roman authors such as Cicero and Seneca (Sjöberg-Ramnelius 1694; Sjöberg-Mether 1694). Disputations on politics, on the other hand, were strongly influenced by the modern school of natural law, especially Samuel Pufendorf but also Hugo Grotius (Sjöberg-Rootkirch 1696; Sjöberg-Borg 1697; Sjöberg-Wagner 1698; Sjöberg-Meurch 1699), and this was also the case with disputations presided over by other professors (e.g. Dau-Melitz 1694). In one particular case, Sjöberg presided over a disputation that discussed the possibility of studying ethics using mathematical methods (Sjöberg-Merling 1694). To pose the question in such a manner was a direct attack on the Peripatetic school, considering that Aristotle himself had in Magna moralia criticised Pythagoras, "for by reducing the virtues to numbers he submitted the virtues to a treatment which was not proper to them" (Aristotle 1915, bk. I). The disputation by Merling, named Magna moralia in a clear reference to Aristotle, could draw on young Samuel Pufendorf's attempt in the Elements of law (1660) to study the discipline of

${ }^{44}$ His Politica methodice digesta was definitely available at the university library during the Gustavo-Carolina period (Tering 1982, 248). 
moral philosophy by the methods of "demonstrative" sciences (Pufendorf 2009, pref.). On the whole, compared to the Academia Gustaviana period, the topics of disputations tended to be narrower, the students tried to focus on the argument rather than on distinctions, and there were no accounts of an entire discipline in genere that had been a popular student topic in the 1640 s and 1650 .

\section{Conclusions}

In the Academia Gustaviana period (1632-1656), strong Ramist influences moulded the idea of academic teaching. Based on the guidelines expressed in constitutions, there existed several deviations from the traditional understanding of the position and divisions of philosophy. Most glaringly, metaphysics was completely absent from the curriculum and disputations. Of the traditional sub-disciplines of theoretical philosophy, only mathematics and physics were taught. It is noteworthy that to dispute on the nature and classification of philosophy and its sub-fields was a popular topic during the first decades of the university. Ramism, however, offered no substantive alternative to the Aristotelian philosophical system, which provided the tools and concepts for dealing with all philosophical sub-disciplines. Thus it is not surprising that during the 1640 , especially after the death of Johan Skytte, Aristotelianism regained much of its position at the University of Tartu. Still, this development did not result in the reinstatement of metaphysica in the curriculum. This happened only after the re-establishment of the university in 1690 (the Gustavo-Carolina period), when a professorship for theoretical philosophy was created. Also, practical philosophy (philosophia practica or philosophia civilis) only truly established itself as an independent and coherent academic discipline in the second period of the University of Tartu when a special professorship was instituted for its instruction. Prior to that, the discipline was divided between the professors of logic and history, which shows that the formal classification of knowledge did not always determine the methods of teaching at the universities. Throughout the seventeenth century, disputations on physical, ethical, political, etc. subjects were also led by other professors in the faculty. In the Academia Gustavo-Carolina period, despite a strong emphasis on Aristotle's textbooks in the modified statutes of 1689, Aristotelianism gave way to modern philosophical currents, namely Cartesianism and natural law. 


\section{Bibliography}

\section{Disputations}

Andreae, Ericus [P], Johannes Nicolaus Trätz [R]. (1640). Disputatio de oeconomica in genere. Dorpat.

Cameen, Sueno [P], Petrus Barthelius [R]. (1693). Dissertatio philosophica de spectris. Dorpat.

Crellius, Joachim [P], Petrus Laurentius [R]. (1652). Disputatio philosophica de philosophia in genere. Dorpat.

Dimberg, Sven [P], Laurentius Höjer [R]. (1693). Dissertationcula physica de genesi metallorum. Dorpat.

Dau, Michael [P], Abrahamus Carstenius [R]. (1699). Exercitatio physica de sensibus brutorum. Pernau.

Dau, Michael [P], Andreas Melitz [R]. (1694). Dissertatio philosophica de lege naturali. Dorpat.

Erici Stregnensis, Johannes [P], Andreas Arvidi Stregnensis [R]. (1647). Disputatio physica de plantis. Dorpat.

Erici Stregnensis, Johannes [P], Faderus Uraelius [R]. (1642). Disputatio philosophica de philosophia in genere. Dorpat.

Erici Stregnensis, Johannes [P], Andreas Flojerus [R]. (1651). Disputatio philosophica de natura et constitutione scientiae naturalis. Dorpat.

Erici Stregnensis, Johannes [P], Daniel Gruuf [R]. (1652). Disputatio de mathesi in genere. Dorpat.

Erici Stregnensis, Johannes [P], Ericus Holstenius [R]. (1646). Disputatio physica de metallis. Dorpat.

Erici Stregnensis, Johannes [P], Ericus Holstenius [R]. (1647). Disputatio philosophica inauguralis de substantia. Dorpat.

Erici Stregnensis, Johannes [P], Andreas Malmenius [R]. (1651). Disputatio philosophica de philosophia in genere. Dorpat.

Erici Stregnensis, Johannes [P], Haquinus Platinus [R]. (1641). Disputatio philosophica de astronomiae natura. Dorpat.

Erici Stregnensis, Johannes [P], Jonas Johannis Scarensis [R]. (1645). Disputatio philosophica de philosophiae natura et constitutione. Dorpat.

Erici Stregnensis, Johannes [P], Jonas Johannis Scarensis [R]. (1646). Disputatio de politicae natura in genere. Dorpat.

Erici Stregnensis, Johannes [P], Petrus Schonbergius [R]. (1643). Disputatio physico-astronomica de stellis. Dorpat. 
Erici Stregnensis, Johannes [P], Petrus Trottonius [R]. (1640). Disputatio politica prima de natura et constitutione politices in genere. Dorpat.

Erici Stregnensis, Johannes [P], Petrus Undenius [R]. (1642). In octo libros physic. Arist. $\pi \epsilon \rho i \tau \tilde{\eta} \varsigma \phi v \sigma \iota \kappa \tilde{\eta} \varsigma \alpha \dot{\alpha} \kappa \rho o \alpha ́ \sigma \epsilon \omega \varsigma$ sive de naturali auscultatione disputatio prima. Dorpat.

Erici Stregnensis, Johannes [P], Matthias Wåltt [R]. (1652). Disputatio physica de anima rationali. Dorpat.

Lidenius, Petrus [P], Johannes Dryander [R]. (1654). Disputatio philosophica inauguralis de veritate. Dorpat.

Lidenius, Petrus [P], Johannes Sundius [R]. (1653). Discursus ethices naturam generaliter adumbrans. Dorpat.

Ludenius, Laurentius [P], Michael Bostadius [R]. (1641). Disputatio philosophica de tempore. Dorpat.

Ludenius, Laurentius [P], Petrus Langius [R]. (1639). Oeconomica. Dorpat.

Oldenburg, Heinrich [P], Nicolaus Prytz [R]. (1633). Disputatio physica de terra. Dorpat.

Preusius, Johannes Georgius [P], Stephani Halenus [R]. (1655). Disputatio psychologica de sensibus. Dorpat.

Sarcovius, Daniel [P], Gudmundus Krook [R]. (1699). Disputatio pneumatologica de mente humana in statu separato. Pernau.

Sandhagen, Andreas [P], Matthaeus Libeheer [R]. (1643). Disputatio de speciebus reipublicae. Dorpat.

Savonius, Michael [P], Benedict Anethulander [R]. (1632). Disputationes aliquot de philosophia in genere, I. De philosophiae definitione tam nominali quam reali. Dorpat.

Savonius, Michael [P], Matthias Laechlin [R]. (1644). Disputatio philosophica de natura ethicae. Dorpat.

Michael Savonius [P], Georgius Zethraeus [R]. (1632). Disputatio II. de philosophia in genere quae est de arte, eiusque natura, cui analogustractatus[!] est peripateticorum de quinque habitibus intellectualibus ex 6. ethicorum desumptus, quem Alstedius sub titulo De hexilogia persequitur. Dorpat.

Schelenius, Joachim [P], Andreas Arvidi Stregnensis [R]. (1645). Disputatio de natura mathesios. Dorpat.

Schomerus, Petrus [P], Christiernus Osaengius [R]. (1634). Disputatio solennis philosophica de anima vegetativa. Dorpat.

Schomerus, Petrus [P], Nicolaus Prytz [R]. (1634). Disputatio psychologica 
de anima in genere. Dorpat.

Sjöberg, Gabriel [P], Andreas Borg [R]. (1697). Excercitium academicum quo libertas civilis. Dorpat.

Sjöberg, Gabriel [P], Magnus Gabriel Edenius [R]. (1690). Liber philosophus. Riga.

Sjöberg, Gabriel [P], Andreas Kiemmer [R]. (1698). Exercitium academicum de cura animi. Dorpat.

Sjöberg, Gabriel [P], Gudmundus Krook [R]. (1696). Dissertatio philosophica de anima hominis seu mente humana. Dorpat.

Sjöberg, Gabriel [P], Christoph Merling [R]. (1694). Magna moralia sive de mathesi morum cogitatiunculae. Dorpat.

Sjöberg, Gabriel [P], Johannes Mether [R]. (1694). Dissertatio academica de amicitia. Dorpat.

Sjöberg, Gabriel [P], Henricus Meurch [R]. (1699). Disputatio politica de jure principis circa sacra. Dorpat.

Sjöberg, Gabriel [P], Johannes Ramnelius [R]. (1694). Dissertatio ethica de virtute heroica. Dorpat.

Sjöberg, Gabriel [P], Johannes Rootkirch [R]. (1696). Exercitatio politica de majestate. Dorpat.

Sjöberg, Gabriel [P], Jacobus Wagner [R]. (1698). Dissertatio politica exhibens obligationem civium erga principem. Dorpat.

Sjöberg, Gabriel [P], Andreas Westermann [R]. (1692). Dissertatio philosophica de erroribus sensuum. Dorpat.

Wexionius, Olaus [P], Benedictus Ekaeus [R]. (1655). Discursus practicus de politices constitutione. Dorpat.

\section{Other sources and literature}

Alsted, J. H. (1649). Ioan. Henrici Alstedii Scientiarum omnium Encyclopaediae: Tomus primus, Sumptibus Ioannis Antonii Huguetan Filij, \& Marci Antonii Ravaud, Lyon.

Althusius, J. (1995). Politica, Liberty Fund, Indianapolis.

Annerstedt, C. (1877). Upsala Universitets Historia: Bihang I: Handlingar, 1477-1654, W. Schultz, Upsala.

Annerstedt, C. (ed.) (189o). Upsala universitets konstitutioner af år 1655, Upsala universitets årsskrift.

Aristotle (1915). Magna moralia, The Works of Aristotle, Clarendon Press, 
Oxford. Translated by W.D. Ross.

Aristotle (1933). Metaphysics, Aristotle in 23 Volumes, Harvard University Press, Cambridge, MA. Translated by Hugh Tredennick.

Aristotle (200o). Nicomachean Ethics, Cambridge University Press, Cambridge. Edited by Roger Crisp.

Boethius (1983). Boethian Number Theory: A Translation of the De Institutione Arithmetica (with Introduction and Notes), Rodopi, Amsterdam. Translated by Michael Masi.

Carney, F. S. (1995). Foreword, in J. Althusius (ed.), Politica, Liberty Fund, Indianapolis.

Catalogus (1653). Catalogus lectionum publicarum. Copy in: Tartu University Library manuscript collection, Acad. Dorp. 1653:20. Reprinted in: Karl Inno. 1972. Tartu University in Estonia during the Swedish rule (16321710). Stockholm: Förlag Vaba Eesti, 70.

Catalogus (1694). Catalogus lectionum publicarum, quas professores Academiae Dorpatensis ab autumno anni 1694. ad annum sequentem ejusdem temporis studiosae juventuti proponere decreverunt, Dorpat. Copy in: Tartu University Library manuscript collection, Acad. Dorp. 1694:20.

Catalogus (1695). Catalogus lectionum publicarum, quas professores Academiae Dorpatensis ab autumno anni 1695. ad annum sequentem ejusdem temporis studiosae juventuti proponere decreverunt, Dorpat. Copy in: Tartu University Library manuscript collection, Acad. Dorp. 1695:18.

Catalogus (1696). Catalogus lectionum publicarum, quas professores Academiae Dorpatensis ab autumno anni 1696. ad annum sequentem ejusdem temporis studiosae juventuti proponere decreverunt, Dorpat. Copy in: Tartu University Library manuscript collection, Acad. Dorp. 1696:35.

Catalogus (1699). Catalogus lectionum publicarum, quas professores ab anni M.DC.XCIX. mense Septembri, ad idem tempus sequentis anni, in Academia Pernaviensi, bono cum Deo, habituri sunt, Pernau. Copy in: Tartu University Library manuscript collection, Acad. Dorp. 1699:13.

Chang, K. (2004). From oral disputation to written text: The transformation of the dissertation in early modern Europe, History of Universities 19: 129187.

Condren, C., Gaukroger, S. and Hunter, I. (2006). The Philosopher in Early Modern Europe: The Nature of a Contested Identity, Cambridge University Press, Cambridge.

Constitutioner (1690). Kongl. Academiens i Dorpt Constitutioner förswenskade. Tartu University Library manuscript collection, F. 7, s-ü 2. 
Di Biase, G. (2014). Theologia, ethics, and natural law in Locke's classifications of knowledge and Adversaria, Locke Studies 14: 177-237.

Freedman, J. S. (1988). European Academic Philosophy in the Late Sixteenth and Early Seventeenth Centuries: The Life, Significance, and Philosophy of Clemens Timpler (1563/4-1624), Studien und Materialien zur Geschichte der Philosophie, Olms, Hildesheim.

Freedman, J. S. (1999). Introduction-The study of sixteenth- and seventeenth-century writings on academic philosophy: Some methodological considerations, Philosophy and the Arts in Central Europe, 150o170o: Teachings and Texts at Schools and Universities, Variorum Collected Studies 626, Ashgate, Aldershot, pp. 1-40.

Garstein, O. (1992). Rome and the Counter-Reformation in Scandinavia, 3. Jesuit Educational Strategy, 1553-1622, Studies in the History of Christian Thought 46, Universitetsforlaget, Copenhagen.

Golius, T. (1592). Epitome doctrinae moralis: Ex decem libris ethicorum Aristotelis ad Nicomachum collecta, Josias Rihel, Argentorati.

Golius, T. (1622). Epitome doctrinae politicae: Ex octo libris Politicorum Aristotelis collecta, Josias Rihel, Argentorati.

Hotson, H. (2007). Commonplace Learning: Ramism and its German Ramifications, 1543-1630, Oxford University Press, Oxford.

Imhausen, A. and Remmert, V. R. (2006). The oration on the dignity and the usefulness of the mathematical sciences of Martinus Hortensius (Amsterdam, 1634): Text, translation and commentary, History of Universities 21: 71-150.

Ingemarsdotter, J. (2011). Ramism, Rhetoric and Reform: An Intellectual Biography of Johan Skytte (1577-1645), Acta Universitatis Upsaliensis. Uppsala Studies in History of Ideas 42, Edita Västra Aros, Västerås.

Iwakuma, Y. (1999). The division of philosophy and the place of the trivium from the 9th to mid-12th centuries, in S. Ebbesen and R. L. Friedman (eds), Medieval Analyses in Language and Cognition, Kgl. Danske Videnskabernes Selskab, Copenhagen, pp. 165-189.

Kallinen, M. (1995). Change and Stability: Natural philosophy at the Academy of Turku (1640-1713), Studia historica 51, Suomen historiallinen seura, Helsinki.

Kallinen, M. (2006). Lectures and practices. The variety of mathematical and mechanical teaching at the University of Uppsala in the 17th century, in M. Feingold and V. N. Brotóns (eds), Universities and Science in the Early Modern Period, Springer, Dordrecht, pp. 111-125. 
Korhonen, T. (2016). Peri Psychogonias and other Greek dissertations supervised by Johannes Gezelius the Elder, in J. Päll and I. Volt (eds), Hellenostephanos. Humanist Greek in Early Modern Europe. Learned Communities between Antiquity and Contemporary Culture, Acta Societatis Morgensternianae 6-7, Tartu University Press, Tartu.

Lindberg, B. (1976). Naturrätten i Uppsala 1655-1720, Acta Universitatis Upsaliensis. Skrifter rörande Uppsala universitet. C. Organisation och historia 33, Almqvist \& Wiksell, Uppsala.

Lindborg, R. (1965). Descartes i Uppsala: Striderna om "nya filosofien" 16631689, Lychnos-Bibliotek 22, Almqvist \& Wiksell, Stockholm.

Malmström, Å. (1985). Juridiska fakulteten i Uppsala. Studier till fakultetens historia II. Den juridiska fakulteten under 16oo-talet och början av 17ootalet, Acta Universitatis Upsaliensis. Skrifter rörande Uppsala universitet. C. Organisation och historia 48, Almqvist \& Wiksell, Uppsala.

Meer, J. M. v. d. (2014). European Calvinists and the study of nature: Some historical patterns and problems, in G. van den Brink and H. Höpfl (eds), Calvinism and the Making of the European Mind, Brill, pp. 103-130.

Metallidis, G. (2006). Theology and gnoseology and the formulation of doctrine in St. John Damascene, Studia patristica XLII: 341-346.

Ong, W. J. (2004). Ramus, Method and the Decay of Dialogue. From the Art of Discourse to the Art of Reason, The University of Chicago Press, Chicago.

Piirimäe, H. (ed.) (1982). Tartu Ülikooli ajalugu 1632-1982. I köide, 1632-1798, Valgus, Tallinn.

Pufendorf, S. (2009). Two Books of the Elements of Universal Jurisprudence, Liberty Fund, Indianapolis. Edited and with an Introduction by Thomas Behme.

Ramus, P. (1569). P. Rami Scholae in liberales artes: Quarum elenchus est proxima pagina, per Eusebium Episcopium, \& Nicolai F. haeredes, Basileae.

Ramus, P. (2010). Arguments in Rhetoric Against Quintilian: Translation and Text of Peter Ramus's Rhetoricae Distinctiones in Quintilianum, SIU Press, Carbondale and Edwardsville. Edited by James J. Murphy. Translated by Carole Newlands.

Rauch, G. v. (1943). Die Universität Dorpat und das Eindringen der frühen Aufklärung in Livland, 1690-1710, Essener Verlagsanstalt. Schriftenreihe Schweden und Nordeuropa 5.

Rein, K. (2008). Andreas Arvidi disputatsioon De natura et constitutione medicinae arstiteadusliku mõtte arengu peegeldajana 17. sajandi Tartu Ülikoolis, Mäetagused 39: 7-28. 
Rein, K. (2016). Johannes Raicuse käsitlus Tartu linnast ja selle ümbrusest, Akadeemia 28: 225-235.

Runeby, N. (1962). Monarchia mixta: Maktfördelningsdebatt i Sverige under den tidigare stormaktstiden, Studia historica Upsaliensia 6, Svenska bokförlaget, Stockholm.

Ruutsoo, R. and Luik, T. (1982). Humanitaarteadused.Filosoofia, in H.Piirimäe (ed.), Tartu Ülikooli ajalugu. Kolmes köites 1632-1798, Valgus, Tallinn, pp. 181-189.

Sainio, M. A. (1962). Ramismen vid universitetet i Dorpat, Studia Historica Jyväskylensia I, pp. 250-274.

Sjöberg, G. (1692). Metaphysica contracta. In qua utiliores definitiones, divisiones ac distinctiones ex fontibus Arist. adcuratiorumque hujus temporis metaphysicorum scriptis, junctis selectioribus quaestionibusex theol. desumtis, in usum \& gratiam harum amantium in Regia Academia Dorpatensi, ea brevitate, qua poterat, proponuntur a Gabriele Siöbergh. phil. theoret. profess. ord. Dorpati, typis Johannis Brendeken, Acad. Typograph (Dorpat: J. Brendeken).

Tering, A. (1982). Ülikooli raamatukogu, in H. Piirimäe (ed.), Tartu Ülikooli ajalugu 1632-1982. I köide, 1632-1798, Valgus, Tallinn, pp. 243-254.

Vasar, J. (ed.) (1932). Tartu Ülikooli Ajaloo Allikaid. Quellen Zur Geschichte Der Universität Tartu (Dorpat). I, Academia Gustaviana: A) Urkunden und Dokumente, Tartu Ülikool, Tartu. 